\title{
Alternative forced-molting methods in japanese quails
}

\author{
Métodos alternativos de muda forçada para codornas japonesas
}

\author{
SILVA, Daiane Batista ${ }^{*}$; MACIEL, Mônica Patrícia ${ }^{1}$; AROUCA, Cláudio Luiz \\ Corrêia $^{1}$; AIURA, Felipe Shindy ${ }^{1}$; SOUZA, Luiz Felipe Martins ${ }^{1}$; MOURA, Vitor Hugo \\ Santana de ${ }^{1}$
}

${ }^{1}$ Universidade Estadual de Montes Claros, Departamento de Ciências Agrárias, Janaúba, Minas Gerais, Brasil.

*Endereço para correspondência: daianebatistas88@yahoo.com.br

SUMMARY

The aim of this study was to evaluate the effects of different forced-molting methods on the performance and quality of laying quail eggs. The experiment was conducted in a conventional shed for quails and lasted 115 days. 480 Japanese quails at an initial age of 52 weeks were used. The following treatments were evaluated: total feed fasting (control treatment); corn and soybean bran diet; highzinc diet $(7,300 \mathrm{ppm})$; wheat bran diet; and ground corn diet. A fully randomized experimental outline was used with 5 treatments and 4 repetitions. Each lot was formed by 24 quails with a total of 480 birds. Performance (production and egg weights, feed intake, feed conversion ratio per $\mathrm{kg}$ egg mass and per dozen eggs, viable eggs and egg viability) and egg quality (eggshell thickness and yield, specific weight and Haugh unit) were evaluated. Treatment differences were compared using the Scott-Knott test (5\%). Wheat bran and highzinc diets yielded poorer averages of egg production and feed conversion ratioper dozen eggs. Studied treatments had no influence on egg quality. Hence, we can conclude that cornonly or corn and soybean bran only feeds can be adopted as forced molting methods in Japanese quails instead of traditional fasting methods.

Keywords: egg quality, fasting, quail farming, performance

\section{RESUMO}

Objetivou-se com esta pesquisa avaliar a ação de diferentes métodos de muda forçada sobre o desempenho e qualidade dos ovos de codornas de postura. O experimento foi conduzido em um galpão convencional para codornas e teve duração de 115 dias. Foram utilizadas 480 codornas japonesas, com idade inicial de 52 semanas. Os tratamentos avaliados foram: Jejum total de ração (tratamento testemunha); Ração constituída de milho e farelo de soja; Ração com alto nível de Zn (7.300 ppm); Fornecimento de farelo de trigo; Fornecimento de milho moído. O delineamento experimental utilizado foi inteiramente casualizado, com 5tratamentos e 4 repetições. Cada parcela foi constituída de 24 codornas, totalizando 480 aves. Foram avaliadas características de desempenho (produção e peso de ovos, consumo de ração, conversão alimentar, por massa e por dúzia, ovos viáveis e viabilidade) e qualidade de ovos (espessura e rendimento de casca, peso específico e unidade Haugh). As diferenças entre os tratamentos foram comparadas pelo teste Scott-Knott (5\%). Os tratamentos constituídos por farelo de trigo e ração com alto nível de zinco proporcionaram piores produções médias de ovos e conversão alimentar por dúzia de ovos. Não houve influência dos tratamentos sobre as características de qualidade de ovos. Pode-se concluir que o fornecimento de somente milho ou somente milho e farelo de soja podem ser adotados como métodos de muda forçada para codornas japonesas em substituição ao jejum.

Palavras-chave: qualidade de ovos, jejum, coturnicultura, desempenho 


\section{INTRODUCTION}

A quail's productive life lasts approximately one year and can extend itself to one year and a half. However, as in egg-laying hens, production declines with age and is followed by poorer egg quality (ALBINO \& BARRETO, 2012). Therefore, forced molting has appeared as a mean to extend quail productive life and improve egg quality so egg-layers can have a second laying cycle more quickly.

According to Scherer et al. (2009), forced molting allows weight loss and consequent reproductive tract regression, as well as, posterior epithelial development and regeneration which improve egg production and quality.

Total feed restriction to achieve an approximate 25 to $30 \%$ body weight reduction has been the most used forced molting technique in egg-laying hens, mainly because it is easy to perform, less costly and produces satisfactory postmolt performance results. Nevertheless, the fasting technique has not been considered adequate by several countries for it is seen as too severe and promotes a significant body weight reduction in a short period of time (SOUZA et al., 2010). Moreover, molting causes immunological depression in subjected birds; therefore, it can lead to serious sanitary issues in lots such as salmonellosis, which can contaminate eggs for human consumption (TEIXEIRA et al., 2013). Ergo, alternative feed restriction-less methods, which consequently generate less free oxygen radicals, have been more favorably considered since they allow better welfare conditions to egg-layers.

Unlike what happens in egg-laying hen farms, alternative techniques to forced molting by fasting have not been widely reported in egg-laying quail farmsand information on this topic is scarce in scientific literature. Teixeira et al. (2009) compared the fasting and highzinc $(25,000 \mathrm{ppm}$ of zinc oxide) methods in Japanese quails and noted that between the second and fourth weeks of postmolt production, those who received high-zinc diets and had a $25 \%$ body weight loss showed better production results. However, no differences were found between the fasting and high-zinc methods regarding egg production after the third week. Yet, Santos et al. (2014) noted reproductive tract regression in European quails who received only wheat bran for 12 and 16 days.

Due to what has been previously described above, this study aimed at evaluating different forced-molting methods after treatment application, on the performance and egg quality of egglaying quail eggs.

\section{MATERIALS AND METHODS}

All animal procedures were approved by the Committee for Ethics in Animal Experimentation and Welfare of the university (085 number process).

The experiment was conducted in a commercial quail farm located in the city of Nova Porteirinha, Northern Minas Gerais State. Japanese quails at an initial age of 52 weeks were used. The quails were raised in an intensive farming system which consisted of a conventional quail warehouse equipped with 20 cages with 24 quails per cage. The experimental outline was fully randomized with 5 treatments and 4 repetitions. Each group was formed by 24 quails with a total of 480 birds.

We evaluated the conventional fasting method (FM) with no supply of feed for 3 consecutive days (GARCIA et al., 2001) and four alternative methods 
which were: corn and soybean branonly feed (CSB); feed containing high levels of zinc $(7,300 \mathrm{ppm})$; wheat branonly feed (WB) and ground corn-only feed (GC) (Table 1). All treatments were applied during 10 days except the fasting method which was applied for 3 days; and water was not restricted during the molting period. During the rest period which includedquail readaptation, egg-laying feed was supplied in a restricted manner. On the first post molt day, $20 \%$ of normal egglaying feed supply $(25 \mathrm{~g})$ was offered (Table 1) to all quails. On the second, third and fourth days, 40,60 and $80 \%$ of normal feed supply was offered, respectively, and, following the fifth day, normal feed supply was offered to all birds. Supplied feed was formulated according to the recommendations of Rostagno et al. (2011) for quails in egglaying phase.

Table 1. Calculated percentages and nutritional levels of feed offered to Japanese quails as an alternative to the fasting molting method and of egg-laying feed offered during posterior egg-laying phase

\begin{tabular}{|c|c|c|c|c|c|}
\hline \multirow{2}{*}{ Item } & \multicolumn{5}{|c|}{ Feed } \\
\hline & CSB & $\mathrm{Zn}$ & WB & $\mathrm{CO}$ & EL \\
\hline \multicolumn{6}{|l|}{ Ingredient } \\
\hline Ground corn & 55.80 & 47.67 & - & 100.00 & 50.00 \\
\hline Soybean bran & 37.20 & 38.52 & - & - & 38.40 \\
\hline Wheat bran & - & - & 100.00 & - & - \\
\hline Inert & 7.00 & - & - & - & - \\
\hline Calcitic Limestone & - & 7.42 & - & - & 7.42 \\
\hline Dicalcium phosphate & - & 1.82 & - & - & 1.82 \\
\hline Soybean oil & - & 2.47 & - & - & 1.47 \\
\hline DL-Methionine(99\%) & - & 0.09 & - & - & 0.09 \\
\hline HCL L-Lysine(78\%) & - & 0.06 & - & - & 0.06 \\
\hline Common Salt & - & 0.45 & - & - & 0.45 \\
\hline Min. andVit. Supl. ${ }^{1}$ & - & 0.50 & - & - & 0.50 \\
\hline Zinc Oxide & - & 1.00 & - & - & - \\
\hline Total & 100.00 & 100.00 & 100.00 & 100.00 & 100 \\
\hline \multicolumn{6}{|c|}{ Calculated nutritional levels } \\
\hline Crude protein(\%) & 21.51 & 22.10 & $15.62^{*}$ & $7.88^{*}$ & 22.01 \\
\hline Metab.En.(kcal/kg) & 2.725 & 2.721 & $1.795^{*}$ & $3.381^{*}$ & 2.725 \\
\hline Calcium(\%) & 0.11 & 3.50 & $0.14^{*}$ & $0.03^{*}$ & 3.50 \\
\hline Available phosph.(\%) & 0.13 & 0.46 & $0.33^{*}$ & $0.06^{*}$ & 0.69 \\
\hline Sodium $(\%)$ & 0.02 & 2.00 & $0.02^{*}$ & $0.02^{*}$ & 2.00 \\
\hline $\operatorname{Zinc}(\mathrm{mg} / \mathrm{kg})$ & 0.002 & 7.300 & $134.5^{*}$ & $21.5^{*}$ & - \\
\hline Digest.methionine(\%) & 0.30 & 0.39 & $0.18^{*}$ & $0.15^{*}$ & 0.41 \\
\hline Digest.lysine( $\%)$ & 1.01 & 1.25 & $0.47^{*}$ & $0.19^{*}$ & 1.25 \\
\hline Digest. Met +Cis(\%) & 0.67 & 0.76 & $0.43^{*}$ & $0.29^{*}$ & 0.76 \\
\hline Digest. threonine(\%) & 0.30 & 0.73 & $0.17^{*}$ & $0.27^{*}$ & 0.84 \\
\hline Digest.triptophane $(\%)$ & 0.20 & 0.24 & $0.19^{*}$ & $0.05^{*}$ & 0.27 \\
\hline
\end{tabular}

$\mathrm{CSB}=$ corn and soybean bran only feed; $\mathrm{Zn}=$ high-zinc feed; $\mathrm{WB}=$ wheat bran-only feed; $\mathrm{CO}=$ cornonly feed; EL= Egg-laying feed. ${ }^{1}$ Guaranteed content (per Kg of product): $\operatorname{zinc}(\mathrm{min}$.$) - 70000mg;$ iodine (min) - $1500 \mathrm{mg}$; copper(min.)- 8500mg; manganese (min.) -75000mg; iron(min.) -50000mg; cobalt- 200mg;folic acid -100mg; pantothenic acid -15620mg; biotine -100mg; niacin 39800mg;vit.A7000000UI; vit.B1 -2000mg;vit.E -50000mg; vit.B12- 3000mg; vit.B2 - 4000mg;vit.B6 - 3000mg ; vit.D3-2100000UI; vit.K3 - 2000mg; selenium -200mg; antioxidant-100000 mg; "Source: Rostagno et al. (2011). 
During the molting period, artificial lighting was removed 5 days before treatment application. After the final molting phase, an increasing lighting program was applied with a 30 minute gradual increase per week until aimed 16-hour daylight program was reached.

Soon after the end of the moult (one day later), the evaluation phase was started with five periods of 21 days (105 days). We analyzed the performance (feed intake, egg production and weight, feed conversion, marketable and viable eggs) and egg quality variables (specific weight, Haugh unit and eggshell yield and thickness).

Results were submitted to variance analysis, using a SISVAR computer program developed by Ferreira (2011). Treatments were compared using the Scott-Knott test at a 5\% probability.

\section{RESULTS AND DISCUSSION}

Mean values of performance characteristic are shown in Table 2 . Only egg production and feed conversion ratio per dozen eggs were affected by treatments $(\mathrm{P}<0.05)$. Wheat bran only feed (WB) yielded lower egg production percentages. This result can be due to the long-term effects of high fiber intake during molting which may have caused a negative impact on the quails in egg-laying phase. Also, quails who underwent alternative treatment during molting and were fed WB showed greater body weight loss and took more time (along with those who received the $\mathrm{Zn}$ treatment) to reach $50 \%$ of egg production (26 days after molting).

Table 2. Average (after the five periods evaluated after forced molting) of egg production Egg production (PROD), feed intake (FI), egg weight (EW), feed conversion ratio per dozen eggs (FCDE), feed conversion ratio per $\mathrm{kg}$ egg mass (FCM), viable eggs (VE) and viability (VB) of Japanese quails according to experimental treatments

\begin{tabular}{lccccccc}
\hline \multirow{2}{*}{ Treatment } & \multicolumn{7}{c}{ Variable } \\
\cline { 2 - 8 } & $\begin{array}{c}\text { PROD } \\
(\%)\end{array}$ & $\begin{array}{c}\text { FI } \\
(\mathrm{g})\end{array}$ & $\begin{array}{c}\text { EW } \\
(\mathrm{g})\end{array}$ & $\begin{array}{c}\text { FCDE } \\
(\mathrm{g} / \mathrm{dz})\end{array}$ & $\begin{array}{c}\text { FCM } \\
(\mathrm{g} / \mathrm{g})\end{array}$ & $\begin{array}{c}\text { VE } \\
(\%)\end{array}$ & $\begin{array}{c}\text { VB } \\
(\%)\end{array}$ \\
\hline FM & $70.2^{\mathrm{a}}$ & 24.3 & 11.4 & $574^{\mathrm{a}}$ & 3.04 & 89.41 & 91.2 \\
$\mathrm{CSB}$ & $75.6^{\mathrm{a}}$ & 25.1 & 11.3 & $508^{\mathrm{a}}$ & 2.90 & 92.94 & 91.6 \\
$\mathrm{Zn}$ & $65.4^{\mathrm{b}}$ & 24.7 & 11.6 & $777^{\mathrm{b}}$ & 3.09 & 90.45 & 93.0 \\
WB & $64.5^{\mathrm{b}}$ & 23.4 & 11.4 & $710^{\mathrm{b}}$ & 3.23 & 90.49 & 94.1 \\
$\mathrm{CO}$ & $72.5^{\mathrm{a}}$ & 23.4 & 11.4 & $439^{\mathrm{a}}$ & 3.27 & 93.41 & 95.5 \\
\hline CV & 5.14 & 6.55 & 3.02 & 15.90 & 7.33 & 2.99 & 3.66 \\
\hline PROB & 0.002 & 0.516 & 0.874 & 0.002 & 0.438 & 0.220 & 0.412 \\
\hline Average \pm & $69.62 \pm$ & $24,19 \pm$ & $11,42 \pm$ & $571,95 \pm$ & $3,05 \pm$ & $91.35 \pm$ & $93,07 \pm$ \\
SE & 1.789 & 0.792 & 0.173 & 45.464 & 0.112 & 1.366 & 1.705 \\
\hline
\end{tabular}

$\mathrm{FM}=$ feed restriction for 3 days; $\mathrm{CSB}=$ corn and soybean bran feed for 10days; $\mathrm{Zn}=$ high-zinc feed for 10 days; $\mathrm{WB}=$ wheat branfeed for 10 days; $\mathrm{CO}=$ corn feed for 10 days; Averages followedby different letters in table lines significantly differ between themselves in the Scott-Knott test $(\mathrm{P}<0.05)$.

The start of egg production is strongly related to average body weight (BRODY et al., 1984). As a result, proper weight must be observed in quails after molting, according to Lima et al. (2011), since quails are lightweight birds and small body weight variations can result in inadequate physical size for reproductive system maturation and beginning of egg laying, 
generating a lower egg production later on.

The quails who received high-zinc feed also showed lower egg production. These quails, after molting, took the longest to reach $50 \%$ of egg production (29 days after molting). According to Machebe et al. (2013), high levels of zinc in feed leads to the accumulation of this element in the bird's liver and kidneys causing a greater demand for detoxification and acid-base balance regulation on these organs. This process adds to the egg production delay since zinc excess in feed also negatively influences progesterone production which is directly related to ovulation (JOHNSON \& BRAKE, 1992).

There was an effect of the periods on the production of eggs, observing a quadratic behavior (Figure 1). The production of quail eggs in the first 21 days post molting was lower due to the recovery of the birds subjected to forced molting methods. Subsequently, production gradually increased again until the fourth period. From this moment it was observed a fall in the production that certainly is related to the advance of the age of the birds (ROCHA et al., 2008; FAITARONE et al., 2008; ALBINO \& BARRETO, 2012).

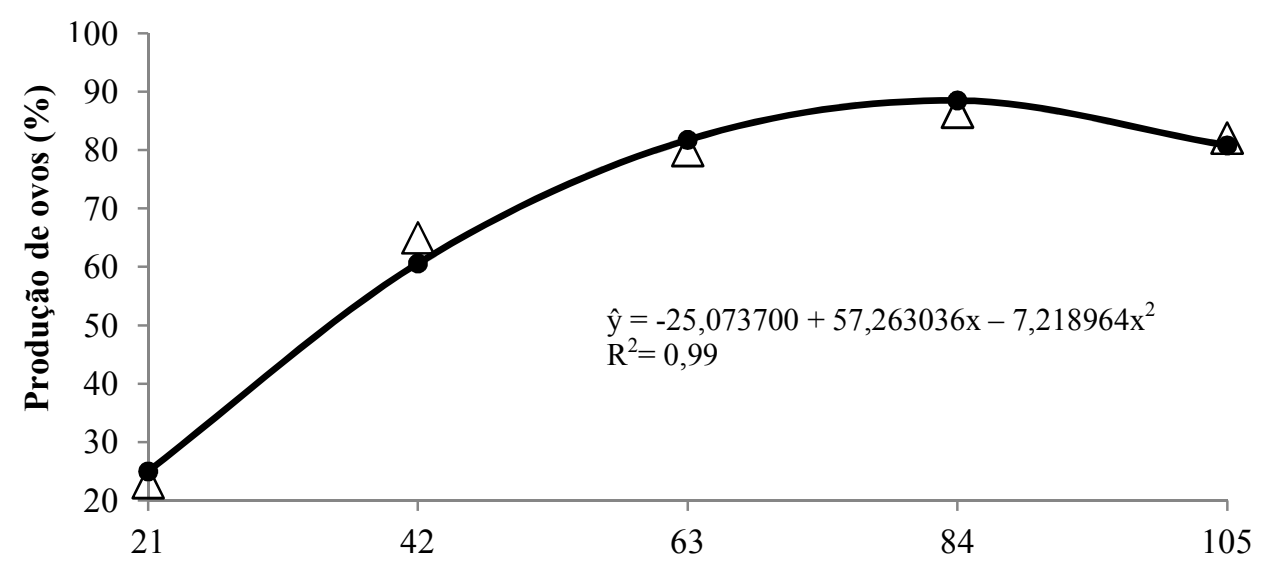

As noted in this experiment, no differences in feed intake were found in quails submitted to different forced molting methods. However, Scherer et al. (2009) observed that semi-heavy egg-layers submitted to fasting molting methods showed greater intake than those who received mineral and aminoacid restricted diets. The authors mention that this behavior, seen in fasting-submitted birds, is probably related to a compensatory weight gain due to weight lost during feed fasting and to the higher productivity of these birds during production phase.
Albino \& Barreto (2012) point out that during egg-laying phase average feed intake equals 25 to $30 \mathrm{~g} /$ bird per day for Japanese and European quails where intake is related to quail size and environmental conditions. In the present experiment, the studied quails consumed smaller amounts of feed which varied from $23.40 \mathrm{~g}$ to $25.60 \mathrm{~g}$. This may have been caused by the high temperatures seen during the experiment $\left(27.64^{\circ} \mathrm{C}\right.$ average). According to Albino \& Barreto (2012), the thermal comfort zone or thermoneutral zone in adult quails is 
much narrower than in other birds, namely between 18 and $22^{\circ} \mathrm{C}$.

Garcia et al. (2002) and Teixeira et al. (2009) did not find any differences in egg weight either, but found inferior values in their study of $10.20 \mathrm{~g}$ and 10.45 , respectively. According to Albino \& Barreto (2012), quail egg weight can vary between 9 to $13 \mathrm{~g}$, depending on age and species. Egg weight values found in this study are similar to those suggested by said authors.

Regarding feed conversion ratio per dozen eggs (FCDE), differences were found between treatments. High-zinc and wheat bran feeds yielded poorer results, which was expected since these treatments also produced the poorest egg production rates.

Unlike the results found in this study, Teixeira et al. (2009) did not find any differences in FCDE results between fasting and high-zinc feed submitted quails. Still, Scherer et al. (2009) did not find differences either for FCDE results when comparing commercial egg-layers submitted to fasting and alternative feed forced molting methods (nutrient restricted and ground corn diets). The authors recommended mineral and amino-acid restricted diets for these yielded better performance results than others.

As for feed conversion ratio per egg mass (FCM), we did not find any differences between treatments. This was also expected since the calculation of this variable takes in to account feed intake and egg weight and considering how both did not show any differences between treatments. Santos et al. (2014) did not find any differences either in FCM in fasting-submitted lightweight hens compared to wheat bran-fed hens.

As for the percentage of viable eggs (VE), no differences were found between treatments. Likewise, Bar et al. (2003) did not find any differences in VE production between hens which underwent fasting, high-zinc diet and zinc, calcium and phosphorous-deficient diet. Similarly, Teixeira et al. (2009) did not find any differences in VE percentages between fasting-submitted and high zinc-fed quail groups.

Regarding quail farming viability, we did not find any differences between the studied treatments with a 93.06\% average. Scherer et al. (2009) did not find any difference between treatments either regarding viability in commercial egglayers submitted to fasting and alternative forced molting methods with calcium, phosphorous, sodium and amino-acid (methionine and lysine) restriction and ground corn supplementation.

As seen in Table 3, no significant differences $(p<0.05)$ were found between forced molting methods on egg quality characteristics (Table 3).

One of the objectives of the forced molting procedure is to improve the physical structure of eggs, since this is an important factor for trade. Leandro et al. (2006) state that poor egg quality is one of the main factors which make eggs unsaleable.

The results obtained in this research reveal no differences between fasting, high- zinc feed and nutrient-restricted diets. Calcium is one of the most important elements for eggshell formation. For instance, it was present in quantities (3 to $3.5 \%$ ) well below recommended amounts (BRANDÃO et al., 2007; ROSTAGNO, 2011; VILAR et al., 2012) in corn and soybean bran $(0.11 \%)$, wheat bran $(0.14 \%)$ and corn $(0.03 \%)$ and was absent in fasting, however, this did not interfere in egg quality. 
Table 3. Average (after the five periods evaluated after forced molting) of Eggshell thickness (ET), Eggshell yield (EY), specific weight (SW) and Haugh unit (HU) of Japanese quail eggs according to experimental treatments

\begin{tabular}{lcccc}
\hline \multirow{2}{*}{ Treatment } & \multicolumn{3}{c}{ Variable } \\
\cline { 2 - 5 } & ET $(\mathrm{mm})$ & EY $(\%)$ & $\mathrm{SW}\left(\mathrm{g} / \mathrm{cm}^{3}\right)$ & HU \\
\hline FM & 0.247 & 7.92 & 1.073 & 90.67 \\
CSB & 0.242 & 7.99 & 1.072 & 91.26 \\
Zn & 0.239 & 7.89 & 1.071 & 90.12 \\
WB & 0.242 & 7.95 & 1.071 & 90.64 \\
CO & 0.237 & 7.83 & 1.071 & 90.98 \\
\hline CV (\%) & 2.69 & 1.56 & 0.10 & 0.93 \\
\hline PROB & 0.296 & 0.418 & 0.065 & 0.424 \\
\hline Average \pm & $0.242 \pm$ & $7.92 \pm$ & $1.072 \pm$ & $90.74 \pm$ \\
SE & 0,003 & 0.062 & 0.000 & 0.420 \\
\hline
\end{tabular}

$\overline{\mathrm{FM}}=$ feed restriction for 3 days; $\mathrm{CSB}=$ corn and soybean bran feeding for 10 days; $\mathrm{Zn}=$ feeding high levels of $\mathrm{Zn}$ for 10 days; $\mathrm{WB}=$ wheat branfeeding for 10 days; $\mathrm{CO}=$ corn feeding for 10 days.

Similar todata observed in this study, Bar et al. (2003) did not find any differences in eggshell thickness in lightweight egglayers in their experiment with fasting, high-zinc diet and calcium, phosphorous and zinc deficient diet. Similar results were obtained by Scherer et al. (2009) in their study which compared fasting, feed containing corn as its sole ingredient and mineral and amino-acid deficient diets in hens with no effect in eggshell thickness. Eggshell yield was not influenced either in the research conducted by Teixeira et al. (2009) which evaluated quails submitted to fasting and a high-zinc diet. Results found by this author and by Faitarone et al. (2008) are similar to those seen in the present experiment $(8 \%$ and $7.7 \%$ averages, respectively). The results found in this research are compatible with those found by Pizzolante et al. (2007) when experimenting with similar-aged quails (54 and 62 weeks) and found a $7.86 \%$ eggshell yield average.

Similar to other variables, treatments did not affect the specific weight of eggs. Specific weight is an estimation of the amount of deposited eggshell and is related to eggshell percentage and thickness (HAMILTON, 1982). Since the studied treatments influenced neither yield nor eggshell thickness, the aforementioned result was already expected. Ergo, alternative methods to fasting did not negatively influence eggshell quality. Similar results were seen by Donalson et al. (2005) and Santos et al. (2014) in studies with different alternative forced molting methods for egg-layers.

No differences in Haugh Unit (HU) results were found in eggs between the evaluated forced molting methods. According to Alleoni \& Antunes (2001), this variable has been used to express albumin quality where the higher the value, the better internal quality of eggs. The average found in this experiment (90.73) is similar to that found by Pizzolante et al. (2007) when studying quails at the end of their egg-laying phase between 54 to 62 weeks (90.11).

In agreement with results found in this research, Santos et al. (2014) also found no differences in HU when submitting egg-layers to fasting and wheat bran only diet. Unlike results found in this study, Scherer et al. (2009) found lower HU egg values in egg-layers who were only fed corn in comparison with those who underwent the traditional fasting molting method. Yet, no differences 
were seen between fasting and mineral and amino-acid deficient feeds.

Given the above, based on the results obtained in this study, it can be concluded that the corn-only or corn and soybean-only diets can be used as alternative forced molting methods in Japanese quails as a substitution to fasting.

\section{REFERENCES}

ALBINO, L.F.T.; BARRETO, S.L.T. Criação de codornas para produção de ovos e carne. Viçosa: Aprenda Fácil, 2012. 268p.

ALEONI, A.C.C.; ANTUNES, A.J. Unidade haugh como medida da qualidade de ovos de galinha armazenados sob refrigeração. Scientia Agrícola, v.58, n.4, p.681- 685, 2001.

BAR, A.; RAZAPHKOVSKY, V.; SHINDER, D.; VAX, E. Alternative procedures for molt induction: practical aspects. Poultry Science, v. 82, p.543550, 2003.

BRANDÃO, P.A.; COSTA, F.G.P.; SILVA, J.H.V.; BRANDÃO, J.S.; NOBRE, J.G.S.; GOULART, C.C. Exigência de cálcio para codornas japonesas (Coturnix coturnix japonica) em postura. Acta Scientiarum. Animal Sciences, v.29, n.1, p.17-21, 2007.

BRODY, T.B.; SIEGEL, P.B.; CHERRY, J.A. Age, body weight and body composition requirements for the onset of sexual maturity of dwarf and normal chickens. British Poultry

Science, v.25, p.245-252, 1984.
DONALSON, L.M.; KIM, W.K.; WOODWARD, C.L.; HERRERA, P.; KUBENA, L.F.; NISBET, D.J.; RICKE, S.C. Utilizing different ratios of alfalfa and layer ration for molt induction and performance in commercial laying hens. Poutry Science, v.84, n.3, p.362-369, 2005.

FAITARONE, A. B. G.;GARCIA, E. A.;PIZZOLANTE, C. C.; MOLINO, A. B.; PELÍCIA, K.; BERTO, D. A. Forced-Molting Method sand Their Effects on the Performance and Egg Quality of Japanese Quails (Coturnix japonica) in the Second Laying Cycle. Brazilian Journal of PoultryScience, v.10, n.1, p.53-53, 2008.

GARCIA, E.A.; MENDES, A.A.; PIZZOLANTE, C.C.; VEIGA, N. Alterações morfológicas e desempenho de codornas poedeiras tratadas com diferentes programas de alimentação no período de repouso, da muda forçada.

Revista Brasileira de Ciência Avícola, v.3, n.3, p.265-273, 2001.

GARCIA, E.A.; MENDES, A. A.; PIZZOLANTE, C. C.; VEIGA, N.; MATTOS, T. K. Alimentação de codornas com milho moído e ração de postura no período pós-jejum durante a muda forçada e seus efeitos sobre o desempenho. Revista Brasileira de Ciências Avícola, v.4, p.119-126, 2002.

HAMILTON, R.M.G. Methods and factors that affect the measurement of egg shell quality. Poultry Science, v.61, n.10, p.2022-2039, 1982.

JOHNSON, A. L.; BRAKE, J. Zincinducedmolt: Evidence for a direct Inhibitory Effect on Granulosa Cell Steroidogenesis. Poultry Science, v.71 p.161-167, 1992. 
LEANDRO, N. S. M.; JARDIM FILHO, R. M.; BRITO, A. B. Granulometria do calcário no desempenho e qualidade da casca de ovos de codornas japonesas. Ciência Animal Brasileira, v.7, n.4, p.381-387, 2006.

LIMA, H.J.A.; BARRETO, S.L.T.; ALMEIDA, R.L.; MELO, D.S.; COSTA, S.L. Restrição dietética de sódio como método alternativo de muda forçada para codornas japonesas. Enciclopédia Biosfera, v.7, n. 13, 2011.

MACHEBE, N. S.; IWEH, P.; ONYIMONYI, A. E.; EKERE, O. S.; ABONYI, F.Zinc Oxide as an Effective Mineral for Induced Moulting: Effects on Post Moult Performance of Laying Hens in the Humid Tropics. Veterinary Science \&Technology, 2013. Available in: $<$ http://www.omicsonline.org/zincoxide-as-an-effective-mineral-forinduced-moulting-effects-on-post-moultperformance-of-laying-hens-in-thehumid-tropics-2157-7579.S11003.php?aid=15927> Access in: March, 09, 2016.

PIZZOLANTE, C.C.; SALDANHA, E.S.P.B.; GARCIA, E.A.; SOUZA, H.B.A.; SCATOLINI, A.M.; BOIAGO, M.M. Efeito do horário de fornecimento de rações contendo diferentes níveis de cálcio sobre o desempenho produtivo e qualidade de ovos de codornas japonesas (Coturnix japonica) em final de produção. Ciência Animal Brasileira, v.8, n.4, p.677-683, 2007.

ROCHA, J.S.R.; LARA, L.J.C.; BAIÃO, N.C.; CANÇADO, S.V.; BAIÃO, L.E.C.; SILVA, T.R. Efeito da classificação dos ovos sobre o rendimento de incubação e os pesos do pinto e do saco vitelino.

Arquivo Brasileiro de Medicina Veterinária e Zootecnia, v.60, n. 4, p. 979-986, 2008.
ROSTAGNO, H.S.; ALBINO, L.F.T.; DONZELE, J.L.; GOMES, P.C.; OLIVEIRA, R.F.; LOPES, D.C.; FERREIRA, A.S.; BARRETO, S.L.T.; EUCLIDES, R.F. Tabelas brasileiras para aves e suínos: composição de alimentos e exigências nutricionais. 3.ed. Viçosa, MG: Universidade Federal de Viçosa, 2011. 259p.

SANTOS, I.C.L.; MACIEL, W.C.; GOMES, V.S.; SAMPAIO, F.P.; MACHADO, D.N.; LIMA, S.V.G.; LOPES, E.S.; SILVA, C.R; BEZERRA, W.G.A.; TEXEIRA, R.S.C. Regressão do aparelho reprodutivo de codornas européias(coturnixcoturnix) submetidas a muda forçada por meio de dieta a base de farelo de trigo. Acta Veterinária Brasílica, v.8, p.101-106, 2014.

SCHERER, M.R.; GARCIA, E.A.; BERTO, D.A.; MOLINO, A.B.; FAITARONE, A.B.G.; PELÍCIA, K.; SILVA, A.P.; MÓRI, C. Efeito dos métodos de muda forçada sobre o desempenho e qualidade dos ovos de poedeiras comerciais durante o segundo ciclo produtivo.Veterinária e

Zootecnia, v.16, p.195-203, 2009.

SILVA, J.H.V.; JORDÃO FILHO, J.; COSTA, F.G.P.; LACERDA, P.B.; VARGAS, D.G.V.; LIMA, M.R. Exigências nutricionais de codornas. Revista Brasileira de Saúde e Produção Animal [online], v.13, n.3, p.775-790, 2012.

SOUZA, K.M.R.; CARRIJO, A.S.; ALLAMAN, I.B.; FASCINA, V.B.; MAUAD, J.R.C.; SUZUKI, F.M. Métodos alternativos de restrição alimentar na muda forçada de poedeiras comerciais. Revista Brasileira de Zootecnia, v.39, p.356-362,2010. 
TEIXEIRA, R.S.C.; CARDOSO, W.M. Muda forçada na avicultura moderna.

Revista Brasileira de Ciência e

Reprodução Animal, v.35, n.4, p.444455, 2011. Available in:

$<$ http://www.cbra.org.br/pages/publicac oes/rbra/v35n4/pag444-455.pdf $>$ Access in: March, 08, 2016.

TEIXEIRA, R.S.C.; CARDOSO, W.M.; LOPES, E.S; ROCHA ,R.C.; SILVA, R.C; ALBUQUERQUE, A.H.; HORN, R.V.; SALLES, R.P.R. Bacteriological Investigation of Microorganisms

(Salmonella sp. and Other

Enterobacteriaceae) in Common Quails

(Coturnix coturnix) Submitted to

Different Forced-Molting Procedures.

Brazilian Journal of Poultry Science, v.15, n.1, p.47-52, 2013.

TEIXEIRA, R.S.C.; CARDOSO, W.M.; SIQUEIRA, A.A.; NOGUEIRA, G.C.; CAMPELLO, C.C.; BUXADÉ, C.C. Aspectos produtivos e qualitativos de ovos de codornas japonesas submetidas a diferentes métodos de muda forçada. Ciência Animal Brasileira, v.10, n.3, p.679-688, 2009.

Data de recebimento: 02/11/2016

Data de aprovação: 04/04/2017 